\title{
The Sea Kings of the North: Scandinavian Scotland in Nineteenth Century Literature
}

Les rois des mers : l'Écosse scandinave dans la littérature du dix-neuvième siècle

\section{Claire McKeown}

\section{(2) OpenEdition \\ 1 Journals}

Electronic version

URL: http://journals.openedition.org/etudesecossaises/1197

ISSN: 1969-6337

\section{Publisher}

UGA Éditions/Université Grenoble Alpes

Printed version

ISBN: 978-2-37747-001-3

ISSN: $1240-1439$

\section{Electronic reference}

Claire McKeown, «The Sea Kings of the North: Scandinavian Scotland in Nineteenth Century Literature », Études écossaises [Online], 19 | 2017, Online since 01 April 2017, connection on 08 September 2020. URL : http://journals.openedition.org/etudesecossaises/1197

This text was automatically generated on 8 September 2020.

(c) Études écossaises 


\title{
The Sea Kings of the North: Scandinavian Scotland in Nineteenth Century Literature
}

Les rois des mers : l'Écosse scandinave dans la littérature du dix-neuvième siècle

\author{
Claire McKeown
}

1 Modern Scottish culture demonstrates a keen interest in Scandinavian connections, not only through literature and television, but also through potential political links. During the lead-up to the independence referendum, comparisons between Scotland and Scandinavia acknowledged similar geographic positions and social settings, as well as the evocative power of older traditions. Viking imagery abounded in pre-referendum media coverage of connections with Scandinavia, with references both to history and to recent reinterpretations, such as the Shetland festival Up Helly Aa. ${ }^{1}$ This is reinforced by a wider UK trend for modern Nordic culture, for example with the popularity of Scandinavian television and crime fiction, which have even found their own Scottish incarnation in Tartan Noir.

2 While literary connections go much further back, in the late 18th and early 19th centuries a similar interest in cultural links with the Nordic countries developed in Britain, with a significant contribution from Scottish writers. In Scottish writing, or writing on Scotland, there is often a specific emphasis on unifying Scottish and Scandinavian cultures through a specific Northern landscape mythology, linked with a proximity to the sea. In this article I will consider this literary inclusion of Scotland in the North, through Scottish literature and cultural commentary on the North, wider comparisons between the two spaces, and a look at how these links are reflected in Scandinavian literature.

3 19th century British interest in Scandinavia cannot be underestimated, as has been demonstrated by Andrew Wawn in The Vikings and the Victorians (2000), Peter Fjågesund and Ruth A. Symes in The Northern Utopia (2003), and Dimitrios Kassis in Representations of the North in Victorian Travel Literature (2015). The North of Europe was, and still is, a destination for travel writing as well as historical and cultural accounts. Many 
Victorian travellers and writers were motivated both by a Rousseauvian fascination with "primitive" or "natural" societies and a desire to create new "national myths" through connections with the North (Fjagesund \& Symes, 2003, pp. 161, 111). The history of the Viking invasions provides well-documented roots for linguistic and cultural features, as well as a wider mythology which plays an important part in British self-image. The Viking revival sparked numerous translations and rewritings of sagas, as British readers became acquainted with a literary past which, while not entirely their own, was becoming an increasingly attractive part of their heritage.

Scotland's geographical position makes it an obvious point of comparison with the Nordic countries, and especially with Norway. The Viking invasions left a Norwegian heritage which survives in the form of place names, mythology and traditions. In areas like Orkney, Shetland and Caithness the Norwegian cultural influence endured long after the Viking invasions, and indeed the Northern Isles can still be seen as a hybrid, Nordic-Scottish region, a vision which is encouraged by cultural events and tourism to Norse settlements like Jarlshof.

5 A trend for translating sagas began at the end of the 18th century, launched in part by Scottish writers like James Johnstone. Johnstone translated sections of Heimskringla and Haakon's Saga, with a particular emphasis on the arrival of Vikings in Scotland (France, 2000, p. 554). Walter Scott was also among the first to participate in this trend, with his abstract of Eyrbyggja Saga which, although based on a Latin translation, was the first English version of a family saga (Clunies Ross, 2010, p. 159). Another significant contributor to the 19th century interest in Old Norse was Samuel Laing. From Orkney, he wrote several accounts of his travels in Scandinavia, and translated Heimskringla in full. As Kassis notes, Laing's treatment of Old Norse material reveals a complex position regarding Scotland's role in the idea of a shared British and Nordic history. His "split cultural image" is clear in the dual aim of his writing; while treating Scotland as "an integral part of Britain", he also seeks the specific similarities between Scotland and Scandinavia, for example comparing the Swedish language with Lowland Scots (Kassis, 2015, p. 82).

Other approaches to the Norse traces left in Scotland also contributed to this trend, with numerous anthropological and linguistic studies into these links appearing in the course of the 19th century. Jamieson's Etymological Dictionary (1808) begins with an essay presenting the author's approach to Scottish language not as derivative of English, but through its other influences, giving specific attention to the Scandinavian roots (pp. XVIII-LIX). Similarly, the anthropologist John Earle seeks scientific and historical bases for his "impressions", and the "popular opinion" that Norway and Scotland are alike (1877, p. 9). He mentions the merging of Nordic and Scottish folklore traditions, but his arguments focus on language. In order to demonstrate the "Danism of [...] the Lowland Scots' dialect", Earle provides a list of words which appear to be "distinctively Scottish" but are Danish in origin, and also cites the Norwegian influence on English in general, which has led to closer phonetic similarities in Scottish English (p. 13). The conclusion returns to his perception of wider similarities between Scotland and Scandinavia, and his hope that more evidence will be provided that "the Scotch language is [...] the great and permanent memorial of the overlapping of the Teutonic and Scandinavian races" (p. 19).

7 Just as Scottish writers contributed to the Viking Revival, sometimes with a specifically Scottish perspective, many English commentators have also compared their 
observations of the Nordic countries with Scotland. In the work of British writers in general, Scotland can at times serve as a more familiar North, in order to give readers a clearer image of Nordic specificities. Many focus on the landscapes; however, the distinctions between interlinked countries also provide a point of comparison. At the end of the 19th century, Edmund Gosse would use British dialects in order to reflect the equally small differences between the Scandinavian languages. He demonstrates the minor variations in Fredrik Hegel's writing between the Danish and Norwegian languages through a more familiar point of comparison: "Now the Norwegian author wrote in a language not more to be distinguished from Danish than Scotch is from English." (Gosse, 1911, p. 40)

8 Placing Denmark and Norway in parallel with England and Scotland makes geographical sense, and historical sense with regard to the specific locations of Viking invasions. As such, descriptions of Norway often include a comparison with Scotland. The ethnologist Robert Gordon Latham uses a familiar British cultural comparison in Norway and the Norwegians:

The civilisation of Norway differs from that of England, as that of Inverness differs from that of London; not as the stages of culture in Isfahan and Paris differ from each other. It is a difference in degree, not of kind. The two countries are on different steps of the same ladder. (1840, p. 2)

This vertical image of Britain and Norway reminds readers that Britain itself stretches to higher latitudes, which are not so far from Scandinavia. This places the differences between England and Norway in a wider context which reduces any notion of extreme cultural disparity; Southern England is no more different, or geographically distant, from Norway than it is from the more peripheral parts of Britain. Latham reinforces this relative proximity by a comparison with a more clearly distant location; while Norway is different from England, it is not so different that it exists on another cultural scale. Norway is no more the "other" than the North of Scotland. Conversely, this also places Scotland on a par with Norway, as part of the distant North, making it distinct from the rest of Britain. Latham's ladder comparison thus makes Scotland into a fluid, adjustable bridge to Scandinavia: neither exclusively British nor entirely Nordic.

George Webbe Dasent also makes use of this convenient perception of Scotland as an in-between place. In his introduction to Popular Tales from the Norse, a collection of tales by Asbjörnsen and Moe, Dasent admits that his translation of the stories cannot communicate the full power of the original version. He hopes that "some of that tenderness and beauty" will still be accessible to readers, but that for those unfamiliar with the North and its culture "no words can tell the freshness and truth of the originals". This difficulty is not linguistic, suggests Dasent, as the languages are "more nearly allied [...] than any other two tongues", it is the "face of the nature herself, and the character of the race that looks up to her, that fails to the mind's eye". He continues this reflection by suggesting how British readers might try to imagine this literary beauty, and the landscape in which it flourished, by comparing it with Scotland: "The West Coast of Scotland is something like that nature in a general way, except that it is infinitely smaller and less grand [...]." (Dasent, 1903, p. CL)

Dasent's comparison presents Scotland as something of a pale reminder of the impressive Norwegian landscape. However, it also suggests that some part of Norway's unimaginable grandeur would be recognisable to anyone familiar with the West coast of Scotland. The Scottish coast once again takes on the role of a bridge, providing a 
point of comparison between the British Isles and Norway. Earle makes a similar suggestion that Scotland possesses a hint of the more impressive Norwegian qualities. The "family likeness" he observes between Norway and Scotland does not indicate an equal distribution of positive traits:

If I were to imagine an ideal Scotchman, tall, fair, square, open, fresh, friendly, cautious, inquiring, practical-though I have seen many such in Scotland, and, indeed, one in particular presents himself now before my mind-yet I think I should give this candidate the second place, and find my beau idéal in the person of a gentleman of the name of Vetlesen, in whose house I was an inmate while I sojourned at Christiania. (Earle, 1877, p. 9)

The ideal Scot is in fact a Norwegian. The most convincing embodiment of Earle's Scottish type is a man he visited in Norway, and although he has encountered versions of the same type in Scotland they fall short of this "beau idéal". This romanticised, mythical version of a familiar stereotype is perhaps typical in the treatment of Scandinavia in British literature and culture: Scandinavian roots provide a reflection of British origins which is "larger than contemporary life" (Elphinstone, 2006, p. 106). Norway is not simply a distant "other", and it provides an intriguing combination of familiarity and exoticism.

In both his personal writing and his fiction R. M. Ballantyne evokes the historical importance of UK-Scandinavian relations, as well as the cultural similarities between these two areas, while also playing with notions of familiarity and exoticism. The final paragraph of his saga-inspired novel Erling the Bold (1869) highlights the importance the Viking characters represent for young British readers:

Yes, there is perhaps more of Norse blood in your veins than you wot of, reader, whether you be English or Scotch; for those sturdy sea rovers invaded our lands from north, south, east, and west many a time in days gone by, and held it in possession for centuries at a time, leaving a lasting and beneficial impress on our customs and characters. We have good reason to regard their memory with respect and gratitude, despite their faults and sins, for much of what is good and true in our laws and social customs, much manly and vigorous in the British Constitution, of our intense love of freedom and fairplay, are pith, pluck, enterprise, and sense of justice that dwelt in the breasts of the rugged old Sea-kings of Norway! (p. 437)

Ballantyne presents these impressive, rather brutal characters as the source of various more conventional virtues associated with British culture and empire building. By reminding readers of their historical significance, Ballantyne also mythologises British culture through its association with the Viking invasions. This romantic view of the "Norse sea kings", seen for example in their imagined "sense of justice", provides a basis for descriptions of their sublime surroundings in Erling the Bold. The novel opens with a "mountain scene of unrivalled grandeur" (p. 1), with the arrival of two boats by the West coast of Norway at sunrise: "A silvery mist hung over the water, through which the innumerable rocks and islands assumed fantastic shapes, and the more distant among them appeared as though they floated in air." (pp. 1-2) This fantastical character is in keeping with Dasent's reflection on the power of the Norwegian countryside, which although unimaginable, is still somewhat similar to the Scottish landscape. Ballantyne's descriptions of Scotland in Freaks on the Fells (1864) hint at a similar notion of Scotland as a point of comparison, and the Scottish landscape seen through the eyes of an English family resembles a diluted version of the Norwegian grandeur. When attempting to convince his wife of the benefits of a stay in Scotland, Mr Sudberry reminds her that the "mountain scenery is grand and majestic beyond 
description" (p. 21). Once there, the landscapes do not disappoint, and contain some of the same dramatic features present in descriptions of Norway:

The mists of early morning were rolling up from the loch in white, fleecy clouds, which floated over and partly concealed the sides of the mountains. The upper wreaths of these clouds, and the crags and peaks that pierced through them were set on fire by the rising sun. Great fissures and gorges in the hills, which at other times lay concealed in the blue haze of distance, were revealed by the mists and the slanting rays of the sun, and the incumbent cliffs, bluff promontories, and capes, were in some places sharply defined, in others luminously softened, so that the mountains displayed at once that appearance of solid reality, mingled with melting mystery, which is seen at no period of the day but early morning. (p. 32)

A sense of mystery and the effects of the meteorological conditions on the landscape still dominate here, and the topographical details and colours produced by the misty sunrise also form a dramatic visual impression. However, while Norwegian mountain scenes are "dark" and "gloomy" in Erling the Bold (p. 42), the Scottish equivalent in Freaks on the Fells is a gentler effect, with emphasis on the soft clouds and the mingling of elements, with "water, earth and sky [...] melting into blue and white masses that mingled with each other in golden and pearly greys of every conceivable variety" (p.33). These distinct aesthetic qualities, sublime in Norway and somewhat more picturesque in Scotland, return to the idea of Scotland as a bridge to the North, and an accessible, homelier version of the more dramatic Northern landscapes.

Ballantyne's work represents these Northern aesthetic similarities while also dealing with more concrete cultural aspects. As in the anthropological observations noted above, linguistic similarities also feature in Ballantyne's treatment of Scotland and Scandinavia, and he cites the ease of communication in both his fiction and his personal writings:
However, it is curious to observe how very small an amount of Norse will suffice for ordinary travellers-especially for Scotchmen. The Danish language is the vernacular tongue of Norway and there is a strong affinity between Danish (or Norse) and broad Scotch. Roughly speaking I should say that a mixture of three words of Norse to two of broad Scotch, with a powerful emphasis and a strong infusion of impudence, will carry you from the Naze to the North Cape in perfect comfort. (1893, available on <www.gutenberg.org/files/21755/21755-h/21755- h.htm>)

17 This amusing observation on how easily a Scot can communicate in Danish or Norse also appears in the novel Chasing the Sun, with the protagonist discovering that his knowledge of Scottish dialect allows him to communicate with a Norwegian friend. In one humorous scene the character is forced to attempt to make himself understood despite speaking little Norwegian, and "at last he terminated in a mixture of bad Norse and broad Scotch". His "knowledge of Lowland Scots" proves useful, as "there is great similarity between it and the Norwegian tongue". (No date, p. 102)

Scottish literary treatments of Scandinavian connections vary between the pragmatic and the romantic, but the landscapes are frequently linked with the weight of history they represent. As Margaret Elphinstone demonstrates, Scandinavian Scotland features in literature spreading from the 12th century to the contemporary period, and often with a positive representation of the Viking influence (2006, p. 105). One example of this "older, more heroic Scotland" (p.112) is Walter Scott's The Pirate. Scott's portrayal of Shetland as a place in which Scottish and Norse ancestries meet, and come into conflict, simultaneously distinguishes between these cultural traditions and shows how 
the lines between them blur. As Elphinstone points out, Scott's character Magnus Troil embodies a primitivist view of the heroic Viking type, while also demonstrating the civilised behaviour of a gentleman. Elphinstone cites the description of Magnus as "strong and masculine" or "ruddy", but also possessed of a "well-conditioned temper" and a sense of hospitality (p. 112).

The Pirate introduces readers to Northern cultural heritage through the incomer Mordaunt's fascination with the sagas:

At this time, the old Norwegian sagas were much remembered, and often rehearsed, by the fishermen, who still preserved among themselves the ancient Norse tongue, which was the speech of their forefathers. In the dark romance of those Scandinavian tales, lay much that was captivating to a youthful ear [...]. (1898, p. 22)

Mordaunt learns of these stories through local oral traditions, which are an important part of the Shetlanders' self-image. Scott's narrative also makes use of knowledge of the sagas, for example by blending prose and poetry. Norna's Song of the Reimkennar is presented rather didactically in the narrative as a "free translation" attempting to render the "terms of expression peculiar to the ancient Northern poetry" (p. 86). Mordaunt is highly receptive to these ancient stories, and also learns to associate them with the specific settings of the Northern Isles:

often the scenes around him were assigned as the localities of the wild poems, which, half recited, half chanted by voices as hoarse, if not so loud, as the waves over which they floated, pointed out the very bay on which they sailed as the scene of a bloody sea-fight; the scarce-seen heap of stones that bristled over the projecting cape, as the dun, or castle, of some potent earl or noted pirate; the distant and solitary grey stone on the lonely moor, as marking the grave of a hero; the wild cavern, up which the sea rolled in heavy, broad, and unbroken billows, as the dwelling of some noted sorceress. (p. 22)

21 While at sea, Mordaunt's surroundings are presented to him as a part of these narratives, and as an incomer to Shetland he learns about the place through its mythological geography. The rich imaginative potential of the landscape makes it particularly well-suited to these stories, and consequently to the dramatic events of Scott's narrative. The physical setting becomes part of the romantic fascination with Norse mythology:

Such legends are, indeed, everywhere current amongst the vulgar; but the imagination is far more powerfully affected by them on the deep and dangerous seas of the north, amidst precipices and headlands, many hundred feet in height,amid perilous straits, and currents, and eddies,-long sunken reefs of rock, over which the vivid ocean foams and boils,- dark caverns, to whose extremities neither man nor skiff has ever ventured,-lonely, and often uninhabited isles,-and occasionally the ruins of ancient northern fastnesses, dimly seen by the feeble light of the Arctic winter. (p. 24)

It is the Northern seas in particular which provide the ideal setting for spectacular stories. Here they are imbued with aspects of the sublime, with extremes of height and depth augmenting their atmosphere of danger and inaccessibility. Scott's emphasis on reduced vision, in the dark caves and the weak polar light, underlines the sense of an unknowable, eternally mysterious part of the world. At this meeting point for Scottish and Norse tradition, the landscape is once again imbued with the specific power we have seen attached to Norway. In the examples from both Ballantyne and Scott this power is linked with masculinity, through images of virile Vikings and wild landscapes waiting to be conquered. Mackey identifies a similar tendency in the "nationalist 
mythology" of Canada as a "Northern wilderness", which also relies heavily on "symbols [which] are deeply 'gendered' and 'raced"' "Death by Landscape: Race, Nature and Gender in Canadian Nationalist Mythology" in Canadian Woman Studies, vol. 20, no. 2, 2000, p. 126). Norna in The Pirate is to some extent a counter-point to this, with her "power over the elements" and air of "stern serenity" and "authority" (Scott, 1898, p. 85). Like Magnus Troil, she is a thoroughly Nordic character, however her power stems from ancient traditions, and her rejection of Christianity makes her a less civilised symbol of Northernness than her male counterpart.

While Scott emphasises the Norse influence on the isles, he also differentiates between this Nordic culture and wider Scottish culture. An agricultural comparison between Scotland and Shetland seems to return to the ladder image used by Latham:

[...] rude as the arts of agriculture were in Scotland, they were far superior to those

known and practised in the regions of Thule. (1898, p. 58)

Triptolemus Yellowley, who comes to Shetland to implement modern farming methods, acts as a point of contrast with the culture of the islanders, but he himself is a mixture of cultures. A biographical narrative on the character reveals that his Scottish mother's marriage with a man from Yorkshire was unpopular with her family, highlighting another North/South cultural gap. Northernness indicates cultural distinctiveness, but this can vary from suggestions of primitivism to differences of character. We learn that Triptolemus's father finds himself farming difficult land as a result of being "come over by a certain noble Scottish earl, proving too far north for canny Yorkshire" (p. 43). This link between Northernness and cunning differs from the representation of relative Northernness in the wider narrative; here mainland Scotland might represent a morally dubious North, while Shetland is associated with both rustic simplicity and moral uprightness. The islanders are portrayed as respecting "laws of hospitality" (p. 4), as exemplified by the generous Magnus Troil. Some of the distinctions between mainland Scottish and Shetland culture are portrayed through differing musical styles; while the "simple music of the North" (p.34) is "melancholy and pathetic" (p. 22), Mordaunt plays the "livelier airs of the North of Scotland" in order to "relieve their monotony" (p. 22). Scott's narrative refers frequently to the nationalities and origins of characters, and indicates the dual identity of the Northern isles through Magnus Troil's two daughters. While Brenda's "healthy complexion" is proof of her "genuine Scandinavian descent" (p. 30), Minna has inherited her "stately form" from their mother, "a Scottish lady from the Highlands of Sutherland" (p. 28). The sisters switch between cultures, and while the more Nordic Brenda prefers the "livelier" Scottish music, Minna is specifically linked with the dramatic Shetland landscape:

She had also a high feeling for the solitary and melancholy grandeur of the scenes in which she was placed. The ocean, in all its varied forms of sublimity and terrorthe tremendous cliffs that resound to the ceaseless roar of the billows, and the clang of the sea-fowl, had for Minna a charm in almost every state in which the changing seasons exhibited them. (p. 31)

The parallel between Minna's deep connection with the landscape, and all its potential for danger and drama, with her love for the pirate Cleveland is at the centre of Scott's narrative. The events are linked with their thematically appropriate setting, and the mixture of Scottish and Nordic traditions link the dramatic 19th century narrative with the older narratives from the sagas. Inclusive approaches to Scotland can also be found reflected in the work of Scandinavian writers. Hans Christian Andersen wrote enthusiastically of his journey 
around Scotland in 1847, and imbues the country with some of the same spectacular, even sublime, beauty Norway has in the work of British writers. He places Edinburgh in the same "picturesque" (Andersen, 1908, p. 485, my translations) category as Stockholm and Constantinople, viewing the whole country as a place of artistic discovery. He is already familiar with Scottish literature, especially Walter Scott, and he recognises some locations from his reading, such as the old Tollbooth prison which, although he deems it of no particular note in itself, nonetheless "attracts the eye" thanks to Scott's writing (p. 486). Later, he travels to Kirkcaldy and believes he has seen Ravenswood castle from The Bride of Lammermoor, until a local corrects him. Andersen reads Scottish places through their literary associations, and as he arrives by train the changing landscape seems to confirm his pre-formed mental images of Scotland:

At last we were by the river which makes the border between England and Scotland; the land of Walter Scott and Burns lay before us, the landscape became mountainous, we could see the sea, the railway ran alongside the coast, a mass of boats lay out there, and finally we reached Edinburgh [...]. (p. 483)

Viewed from the train, Scotland appears to be surrounded by water; the River Tweed forms a border with England, and the sea becomes visible as the journey progresses. The journey to Edinburgh summarises Andersen's vision of Scotland, with a combination of mountains and sea making up a landscape he also associates with Scotland's literary heritage. Referring to himself as a "Danish Walter Scott" (p. 489), Andersen includes this literary history in his own heritage, and mythologises Scotland through contemporary writing in the same way Ballantyne and Scott use Norse literary history.

Andersen appears to refer to notions of relative Northernness when comparing the Scottish landscape with Denmark. When travelling towards Loch Katrine, he concludes that if the Jutland moors are a "still sea", the Scottish moors are "the sea in a storm" (p. 492). Scotland is a step closer to the dramatic Norwegian landscapes, and its seascapes are its most significant feature. Even inland Andersen feels he can hear the "sea rolling" in the sounds of a storm (p.495). Edinburgh is also portrayed with emphasis on the significance of the sea. Princes Street looks like a river-bed (p. 477), and the whole city "spills over into the sea" (p. 485). The short poem inspired by the ruin Andersen takes for Ravenswood presents another condensed version of Andersen's Scotland, with characteristic landscape features and literary significance. The landscape evokes Scott's novel, in a composition made up of the forest and the ruined castle walls, all surrounded by water.

Where the cliff juts into the sea

With beech forests and ivy vines,

Lucy and Edgar of Ravenswood,

Wander into our minds;

Appearing from the castle's ruined walls,

Where the thistle grows and the gull cries,

Around them the great, free nature,

And the sea which sinks and swells!

Speak, forest, of those lovers:

Scotland's Romeo and Juliet. (Andersen, 2000, p. 641)

Just as Scott's portrayal of Orkney links the narrative power of the region with the landscape, here Andersen experiences Scotland as an extension of his literary knowledge of the country. A proximity with the sea is one of the key links between Scotland and Scandinavia. Not only is it a major factor in historical relationships, it also 
allows for contemporary comparisons. While Andersen presents a romantic view of the country influenced by literature, he also notices social similarities with his own. He finds villages in Scotland "impressive [...] but very similar to those of the Sjaelland fishermen", and describes scenes which look Danish, but poorer (Andersen, 1908, pp. 491, 484).

In the Norwegian playwright Bjornstjerne Bjørnson's Maria Stuart i Skottland (1864) geographical comparisons feature less prominently than Nordic-Scottish cultural characterisation. However, Maria's description of her arrival in Scotland hints at the stormy northern seas of The Pirate: "Oh, when I saw Scotland's shores in fog and cold I was standing freezing on the wet deck, then I felt something tingle as fire through my breast, and now I feel it again." (Sahlberg, 1912, p. 114) This first impression of Scotland returns to her as she faces increasing political opposition. The cold sea-scape is threatening to Maria, but essential to the heroic characterisation of Bothwell as a descendant of the Vikings and a modern-day sea rover:

I once stood in for the Orkneys, the ocean tossed us, the clouds flitted like wet sails, the breakers roared, and the coast was treeless and rocky; then I felt my family present, the Norwegian Viking stock that drove ashore here and from which we descend [...]. (p. 178)

31 In the previous scene Bothwell is spurred on by Maria's description of him as "the strongest she knows" (p.175), and here it is this memory of his vigorous Nordic ancestors which gives him the "will" to act (p. 178). The depiction of Bothwell as a man of action thus rests on this image of him as a modern-day Viking, who could be compared with the gentlemanly Viking figure Magnus Troil. Bjørnson's text emphasises the same impressive natural environment, and appears to participate equally in the construction of a shared Northern landscape mythology.

The influential Danish critic Georg Brandes praises Bjørnson's creation of a historically justifiable "Norwegian-Scottish world" (Brandes, 1883, p. 28, my translations). While this allows him to create an appealing portrait of Bothwell, Brandes finds his highly psychological rendering of Maria less successful, as it involves too much "Nordic Idealism" (p. 29). This again refers to notions of relative Northernness and the varying characteristics associated with Nordic spaces. The Northern idealism of Bjørnson's Maria is at odds with Scott's use of "too far North" to suggest slyness, and even within The Pirate varying images of Northernness are attached to Shetland and mainland Scotland. Brandes's reaction indicates the limits of a shared Northern literary identity, suggesting that the mythology surrounding it is too fixed to allow for unlimited personal reinterpretations. A unifying vision of Scotland and Scandinavia relies in part upon stereotypes of Northernness, ranging from virile Vikings to images of rustic simplicity, but these can act as a barrier to convincing characterisation.

In these examples from literature and travel writing, Scotland takes on the role of a bridge between cultures, representing at once the distant Northern reaches of Britain, and a sense of connection with other, more exotic, Northern places. This creates a tension between similarity and difference specific to two cultural spheres which are historically linked, and share some contemporary lifestyle and landscape features. While a "vacillation between the familiar and the alien" (Saïd, 2014, p. 71) is present, this is not quite Orientalism. Although cultural tropes associated with the far North abound, they are placed in a context of shared history and inherited identity. Similar everyday language, as observed by Ballantyne, and social conditions, noted for example 
by Andersen, provide clear similarities giving the sense of rich heritage a more concrete contemporary context. These more pragmatic links seem to justify the more fantastical images of Nordic landscapes and characters, presenting Scotland as a reminder of the sublime landscape native to its Norwegian ancestors. While Viking ancestry provides the basis for writers' depiction of a Scandinavian Scotland, a similar urge is reflected in the work of Scandinavian writers, and in Andersen's writing this creates a more recent sense of literary inheritance. The seascapes presented in Scottish and Scandinavian works combine the sublime with homelier images of the sea, creating a constant interplay between the popular appeal of shared history and the reality of Northern coastal regions.

\section{BIBLIOGRAPHY}

ANDERSEN Hans Christian, 1908, Mit Livs Eventyr, Copenhagen, Gyldendal.

ANDERSEN Hans Christian, 2000, Samlede digte, Copenhagen, Aschehoug.

Ballantyne Robert Michael, 1864, Freaks on the Fells, Philadelphia, John C. Winston.

BAlLANTYNE Robert Michael, 1869, Erling the Bold: A Tale of the Norse Sea-Kings, Philadelphia, Lippincott.

BALLANTYNE Robert Michael, 1893, Personal Reminiscences in Book Making and Some Short Stories, available on <www.gutenberg.org/files/21755/21755-h/21755-h.htm>.

BALLANTYNE Robert Michael, [no date], Chasing the Sun, London, James Nisbet.

BJøRNSON BJøRNSTJERNE, 1864, Maria Stuart i Skottland, Copenhagen, Gyldendal.

Translation: SAHLBERG C. August, 1912, Mary, Queen of Scots; a Drama in Five Acts, Chicago, Specialty Syndicate Press.

BRANDES Georg, 1883, Det moderne gjennembruds maend, en raekke portraeter, Copenhagen, Gyldendal.

CLUNIES Ross Margaret, 2010, The Cambridge Introduction to the Old Norse-Icelandic Saga, Cambridge, Cambridge University Press.

DASENT George, 1903, Popular Tales from the Norse, Edinburgh, David Douglas.

EARLE John, 1877, "On the Ethnography of Scotland", The Journal of the Anthropological Institute of Great Britain and Ireland, vol. 6, London, Trübner \& Co.

ELPHINSTONE Margaret, 2006, "Some Fictions of Scandinavian Scotland », in T. Hubbard and R. D. S. Jack (eds), Scotland in Europe, Amsterdam, Rodopi, pp. 105-117.

FJÅGESUND Peter \& Syme Ruth A., 2003, The Northern Utopia: British Perceptions of Norway in the Nineteenth Century, Amsterdam, Rodopi.

FRANCE Peter, 2000, The Oxford Guide to Literature in English Translation, Oxford, Oxford University Press. 
Gosse Edmund, 1911, Two Visits to Denmark [1872, 1874], London, Smith, Elder \& Co.

JAMIESON John, 1808, An Etymological Dictionary of the Scottish Language, Edinburgh, Edinburgh University Press.

KASSIS Dimitrios, 2015, Representations of the North in Victorian Travel Literature, Newcastle, Cambridge Scholars Publishing.

LATHAM Robert Gordon, 1840, Norway and the Norwegians, vol. 1, London, Richard Bentley.

SAïD Edward W., 2014, Orientalism, New York, Random House.

ScotT Walter, 1898, The Pirate, London, John C. Nimmo.

WAWN Andrew, 2000, The Vikings and the Victorians: Inventing the Old North in Nineteenth Century Britain, Cambridge, DS Brewer.

\section{NOTES}

1. For example, references to Viking heritage can be found in the following articles: Richard Milne, "Scottish Nationalists Look to Nordic Model", Financial Times, 2 February 2014, available on <www.ft.com/content/57664dc2-8bf8-11e3-bcf2-00144feab7de>; Lesley Riddoch, "Look North, Scotland", The Guardian, 5 December 2011, available on <www.theguardian.com/commentisfree/ 2011/dec/05/north-scotland-nordic>; Frank Urquhart, "Scotland to Strengthen Links with Scandinavia", The Scotsman, 7 August 2013, available on <www.scotsman.com/news/scotland-tostrengthen-links-with-scandinavia-1-3033795>.

\section{ABSTRACTS}

Scotland's relationship with the sea is partly defined by links with seafaring Nordic neighbours. Scandinavia is an appealing example of modernity today, but the influence of Viking invasions on Scottish coastal regions has remained a source of intrigue in the popular imagination since the Viking Revival. Scottish writers contributed to this Victorian trend, with Laing's translation of Heimskringla, and Ballantyne's novel Erling the Bold. British writers noted similarities between Scotland and the Scandinavian countries, including features like landscape, character and language. This link also appears in Scandinavian writing, such as HC Andersen's depiction of a Scottish seascape, and Bjørnson's Maria Stuart i Skottland. This paper will examine the construction of a shared Scottish and Scandinavian landscape mythology through literature and cultural commentary.

Les rapports de l'Écosse

à la mer sont indissociables de ceux qu'elle entretient avec ses voisins nordiques. Si la Scandinavie représente aujourd'hui un modèle de modernité, l'impact des invasions

vikings sur les régions côtières de l'Écosse reste une source de fascination dans l'imaginaire populaire, notamment depuis le renouveau viking du dix-neuvième siècle. Plusieurs auteurs écossais de l'ère victorienne prennent part à cette vogue, 
tels Laing, traducteur de la Heimskringla, et Ballantyne dans son roman Erling the Bold. Ils relèvent des similitudes

entre l'Écosse et les pays scandinaves, tant sur le plan de la géographie que sur celui du caractère ou de la langue. Ce rapprochement est aussi le fait d'auteurs scandinaves, dont Andersen à travers ses évocations des paysages maritimes de l'Écosse, et Bjørnson, auteur de Maria Stuarti Skottland. L'article analyse cette construction croisée d'une mythologie des paysages écossais et scandinaves dans quelques récits de fiction et autres écrits de cette époque.

\section{INDEX}

Mots-clés: Walter

Scott, R. M. Ballantyne, Hans Christian Andersen, Bjørnstjerne Bjørnson, traductions de sagas, héritage viking, paysages

littéraires

Keywords: Walter Scott, R. M. Ballantyne, Hans Christian Andersen, Bjørnstjerne Bjørnson, saga translations, Viking heritage, literary landscapes

\section{AUTHOR}

\section{CLAIRE MCKEOWN}

Université de Mulhouse.

Claire McKeown teaches English at Université de Lorraine, and is currently completing a PhD in comparative literature at Université de Mulhouse. Her thesis is entitled "L'implacable lumière du nord : l'impressionnisme littéraire dans la littérature nordique et britannique à la fin du XIX ${ }^{\mathrm{e}}$ siècle". Her research focuses on pre-modernist aesthetics in British and Scandinavian literature, as well as more general links between Northern European cultures. She recently published the articles “'Scandimania' and the Victorians: Exoticism or Self-identification?" in the journal Deshima and "Rapidité et action : techniques impressionnistes chez Henry James et Herman Bang" in Vertiges de la vitesse (éditions Orizons). 